\title{
UTOPÍA Y ASTROLOGÍA EN LA LITERATURA POPULAR DEL SETECIENTOS: LOS ALMANAQUES DE TORRES VILLARROEL
}

El pensamiento utópico se define como un conjunto de vastas aspiraciones, ensueños e ideales de extensos movimientos sociales, que ocurren normalmente en tierra de nadie ${ }^{1}$. Envueltas en el ropaje de la fantasía, se plantean estructuradas y coherentes visiones del mundo. El escritor de utopías del Antiguo Régimen es, con frecuencia, un sabio, aislado del mundo en su despacho o celda, que busca ansioso la piedra filosofal para crear un mundo mejor ${ }^{2}$. Dirige sus escritos a los reyes y a los ministros, o a aquellos sectores privilegiados a quienes aspira a convencer y atraer a causas nobles. La gran profusión de escritores de utopías conocidos a partir de Tomás Moro, creador del género, nos permite trazar esta descripción. En su día gozaron cierta popularidad; en la corte de los Estuardos la Nueva Atlántida (1626) de Francis Bacon fue un best-seller; los Tudores se empapaban con Moro (1516), buen amigo de Enrique VIII y de Erasmo. Sabido es que el texto de Moro inspiró a Shakespeare, en particular la obra Ricardo III, mientras que en el Nuevo Mundo, el primer obispo de Michoacán, Don Vasco de Quiroga, inten-

1 Elaboro aquí datos que entresaco de varios de mis trabajos sobre el siglo Xvin, ahora desde la perspectiva de la utopía y el acto comunicativo. Una versión mucho más breve aparece en mi artículo "Astrology and utopia: The case of Diego de Torres Villarroel", I \& L , 4 (1983), núm. 17, 349-357. Las definiciones sobre la utopía son múltiples, me apoyo sobre todo en JACK H. Hexter, More's utopia: The biography of an idea, Princeton University Press, Princeton, 1952; Ernest Bloch, Das Princip Hoffning, Frankfurt/M., 1959, 2 ts.; Frank Manuel (ed.), Utopias and utopian thought, Beacon Press, Boston, 1967; B. BACZKO, "Lumière et utopie. Problèmes de recherches", AESC, 26 (1971), 355-386; ElisabeTh Hansot, Perfection and progress, MIT Press, Boston, 1976; Gérard Raulet (ed.), Utopie, marxisme selon Emest Bloch, Payot, Paris, 1976; StePhen Greenblatt, Renaissance self-fashioning. From More to Shakespeare, Chicago University Press, Chicago, 1980.

${ }^{2}$ Me parece prudente advertir que si bien ésta es una generalización, algunos datos permiten sustentarla. Moro, consejero de estado, escribió en Flandes su utopía en latín; Tommaso Campanella y Bacon escribieron las suyas mientras estaban en la cárcel. Valga señalar que Moro fue muy conocido en España, a partir de la traducción en 1637, entre los eclesiásticos y medios universitarios. Francisco LóPEz EsTRADA (Tomás Moro y España. Sus relaciones hasta el siglo xoiii, Universidad Complutense, Madrid, 1980) estudia la difusión de Moro y sostiene que su influencia llega hasta el siglo Xvil, en particular a los anónimos autores de La Sinapia y el Tratado sobre la monarquía columbina. 
taba establecer en suelo americano la utopía agraria de Moro, que él consideraba como la perfecta comunidad cristiana. No pocas utopías a partir de entonces se establecerán en el Nuevo Mundo hasta bien entrado el siglo XIX; baste recordar el fracaso cabetiano en Nauvoo, como conspicuo ejemplo.

Este género político-filosófico ha sido motivo de buena cantidad de estudios. Sin embargo, ha pasado desapercibida otra forma de utopía que proyectaba una nueva visión del mundo para el hombre común, sobre todo desde el siglo xviII, y que cruzaba sus aguas con los impulsos humanitarios y reformistas de algunos sectores a partir de Carlos III. Esta nueva vertiente del discurso utópico, que llamaré utopia popular con el propósito de distinguirla, surge en contraste con el discurso culto de los escritores de las minorías privilegiadas, o con los vuelos imaginativos de los novelistas. El primero pocas veces alcanzó gran difusión o llegó a la baja y pequeña burguesía; el segundo, en cambio, contaba con receptores entre las clases populares. A mi juicio, a partir del setecientos, el género utópico tomó dos caminos independientes. La utopía sigue la senda solemne de los escritores cultos, pero es también una ocasión de fantasía oculta bajo el epígrafe general de calendarios y pronósticos, a menudo astrológicos, enderezados al hombre medio ("amigo vulgo"). Este género de utopía popular es fértil terreno de estudio aún poco conocido ${ }^{3}$. El astrólogo diagnosticaba las crisis y enfermedades nacionales y parecía brindar explicaciones científicas para analizar las fuerzas de la naturaleza, así como un nuevo orden que aspiraba a resolver las diferencias sociales. La astrología permitía predecir los males, puesto que la ventura o mala estrella de los pueblos y las personas dependía de conjunciones planetarias. Esta astrología profética es el tema dominante de los astrólogos del siglo xviI, que auguraban glorias o le devolvían a las estrellas la desventura de los pueblos. También se pueden encontrar algunos almanaques y pronósticos animados por el deseo de desmontar los mecanismos de la superstición y la fábula, pues ambos temas alimentan los pronósticos.

Esta forma de utopía que me ocupa, dirigida a las clases populares, es, a mi juicio, un sistema ideológico que emplea la cosmología científica de forma imaginativa y proyecta la armonía en el orden social ${ }^{4}$. El almanaque hunde sus raíces en la obsesión acuciante por el tiempo: el tiempo pasado, el futuro o el tiempo soñado. En cuanto utopía astrológica, los temas de los almanaques constituyen un amplio espectro de

3 Geneviève Bollème (Les almanachs populaires aux xviz et xvïie siècles, Payot, Paris, 1967) no anota ningún ejemplo de utopía en su fundamental estudio sobre los almanaques populares en Francia. Baczko, en cambio, sostiene que la utopía floreció entre 1720-1730 y 1750-1760. Faltan estudios sobre estos temas en la literatura española. Enlazo la utopia popular con la cultura carnavalesca que Bajtín define.

4 Esta que podemos llamar "utopía alquímica" es tema de estudio para ERNEsT BцOCH (op. cit.); sin embargo, mi punto de partida sobre la utopía popular de los almanaques es totalmente distinto. 
los sueños, esperanzas, ambiciones y desencantos de una clase social específica - la del "hombre del pueblo" - que intentaba compensar las discriminaciones y desigualdades sociales por medio de la fantasía. Los almanaques son un manera de utopía, cuya lectura impulsaba a sus lectores a escapar de la asfixia y rigidez social, de las penurias económicas, para sentirse felices. El piscator incorporaba a su lector a un nuevo orden social a través de la pintura idealista o socarrona de las instituciones que el autor defendía. El "lector amigo" o "amigo vulgo" - que llamaré lector social concreto- se dejaba fascinar por las breves fantasías en prosa, por los viajes imaginarios, las anécdotas y descripciones, que si bien sólo trivialmente iluminan experiencias específicas, presentan un mundo más justo, en particular la posibilidad de ascenso social (movilidad social), aspiración real de muchos miembros del estado llano. Encontramos en los almanaques todos los grandes temas y problemas que preocupan a la actividad humana: conocer la influencia de los astros, buscar la salud de acuerdo con una moral respetuosa de la caridad divina y de las necesidades y leýes de la naturaleza. Del pronóstico emerge otro sentido ético, una higiene de vida fundada en la observación de la naturaleza; recomienda la justicia, la virtud y el humanitarismo como base de un nuevo orden social. Nuevo orden asentado en los valores de la pequeña burguesía: bienestar económico, libertad e igualdad. La armonía de clases (bandera de lucha del primer socialismo en el siglo xIX) se podría alcanzar mediante una organización social que permitiera al hombre medio la libertad de escoger puestos y profesiones. El lector concreto de este género, a quien este horizonte de expectativas" alimentaba, era el "vulgo medio, teñido de algunas tierras". Distaba mucho de ser "la gentecilla vahúna", de esas que viven en las barriadas del Barquillo, Lavapiés y Maravillas, según precisa en 1748 un diarista de la Resurrección del Diario de Madrid, o Nuevo Cordón Crítico General de España ${ }^{6}$. Preciso: a partir de algunos trabajos

5 Me apoyo en Hans R. JAUSS, para quien el "horizonte de expectativas" significa una reconstrucción del marco objetivable de expectativas que surge ante cualquier obra en el momento histórico de su publicación (véanse, entre otros, Pour une esthétique de la réception, Gallimard, Paris, 1978; "La jouissance esthétique', Poétique, 39, 1979, 261-274; "Estética de la recepción y comunicación literaria", Punto de Vista, 4, 1981, 34-40). En este sentido, y para los aspectos de recepción, sigo a Jauss; en lo que se refiere al componente textual tomo elementos de WOLFGANG ISER (The act of reading, Routledge \& Keagan, London, 1978) y UMBERTO ECO (A theory of semiotics, Indiana University Press, Bloomington, 1976; The role of the reader: Explorations in the semiotics of texts, Indiana University Press, Bloomington, 1979; Lector in fabula, Bompiani, Milano, 1979). El término "lector implícito", proviene de Iser; es un lector hipotético, no histórico. Por eso distingo entre el lector "implícito" y el "concreto", que sería histórico. Debo subrayar que no dispongo de muchos datos cuantitativos para reconstruir al receptor original de Torres. Así pues, aludo a un horizonte implícito, a falta de documentos; me baso, sin embargo, en la información sobre los ingresos de Torres, las ediciones de sus obras y la cantidad de imitadores que tuvo.

6 Iris M. Zavala, Clandestinidad y libertinaje erudito en los albores del siglo xviii, Ariel, Barcelona, 1978, p. 188. 
recientes, los lectores sociales concretos de la España del Antiguo Régimen pertenecen al clero regular o secular, o bien son letrados (hidalgos, caballeros), miembros de las profesiones liberales o familiares del Santo Oficio. También criados de lujo, pequeños profesionales, regidores de Villa, cómicos, soldados, marinos. De esta somera (nada exhaustiva) división socioprofesional se desprende que el alfabetismo y nivel de escritura es mayor en la ciudad que en el campo $^{7}$. Esta pequeña burguesía es justamente la receptora de los astrólogos y las utopías populares, en su ambición por alcanzar la felicidad material y el bienestar económico. Valga aclarar que el lector social concreto, o receptor coetáneo, proviene de sectores sociales diferentes: cada prólogo prepara al lector y enuncia una práctica social distinta. El diálogo entre emisor y receptor que el piscator establece observa sus estrategias textuales específicas.

El piscator del Antiguo Régimen no tiene pretensiones de profetizar grandes verdades o ilusiones históricas, sino que con arrestos de inventiva, andanadas de disparates y charlatanería, incluso procacidades y sorna, deja deslizar algunas verdades y enseñanzas a sus lectores. Su propósito es sencillo y está en consonancia con la realidad. El mundo de la ficción comunica a sus lectores algo sobre lo que podría ser la realidad. Estas utopías populares están asentadas en útiles consejos para alcanzar la armonía de clases, pero además divertían al público con chistes, enredos, en lenguaje desfachatado y picante. Entre chiste y chiste (o ficción y ficción), se ponen de relieve las primeras esperanzas de aquellos sectores no privilegiados que más tarde se organizarían; sus sueños se traducirían en objetivos muy concretos: los del burgués del siglo XIX.

La astrología proporcionaba una explicación del universo. Todo se producía por azar y cada planeta traía su secuela de beneficios o males: heladas, tempestades, terremotos, invasiones, sequías, lluvias beneficiosas, victorias militares. La miseria y la desolación impulsaban a la búsqueda de explicaciones sobrenaturales, y muchos vasallos encontraban en los augurios de los astrólogos un mundo mejor, una utopía del porvenir, como solución a su presente sombrio ${ }^{8}$. Los astrólogos urdían fantasías y sueños sobre grandezas futuras, y otras veces culpaban a las estrellas de los males. El texto revelaba un mundo de encantamientos y fantasías para un público que conocía la realidad de un mundo hechizado.

Entre los siglos XVII y XVIII el lenguaje y el tema del pronóstico se transforman. Los almanaques son entonces de variado tipo y condición:

7 M. Hafter, "Ambigüedad de la palabra 'público' en el siglo xvin', NRFH, 24 (1975), 46-63 (Homenaje a Raimundo Lida); M.-C. Rodríguez y B. BENNASSAR, "Signatures et niveau culturel des témoins et accusés dans les procès d'Inquisition du ressort du Tribunal de Tolède (1525-1817) et du ressort du Tribunal de Cordoue (1595-1632)", Carav, 1978, núm. 31, 17-46; ZAVAlA, Clandestinidad. . ., y "Entre ciegos anda el libro", en El texto en su historia, Nuestra Cultura, Madrid, 1981, pp. 161-162.

8 Zavala, Clandestinidad..., pp. 175-177. 
un autor, encubierto por rimbombantes títulos — Sarrabal de Milán, Piscator Complutense, Sarrabal Burgalés, Piscator de Salamanca, Jardinero de los Planetas-, mezcla poesía y prosa para predecir el futuro, pero intercalando información más o menos científica sobre el clima, los factores meteorológicos, lunas, mareas. Todos son conocimientos indispensables en una sociedad agraria. Poco a poco se comenzaron a añadir noticias curiosas de índole científica, literaria e instructiva, datos históricos, biografías de reyes y nobles. En otros casos se incluían noticias geográficas, sobre difusión de las matemáticas, noticias médicas; cuando no sanos consejos caseros, o explicaciones sencillas de cómo construir tal o cual objeto artesanal, equivalente a los modernos do-it-yourself books. A veces, entre textos burlescos y chistes de taberna, se desliza una defensa de la nueva ciencia. Estos elementos textuales y contextuales nos indican hoy que algunos almanaques y pronósticos estaban animados por el deseo de desmontar los mecanismos de la superstición y la fábula, en particular los de José Mañer y Basilio Pholt -existe buena cantidad con esta intención ${ }^{9}$. El almanaque del siglo xVII cobra relieve en el vasto contexto de la gran tradición de pronósticos astrológicos de la cual se separa, y figura entre las primeras expresiones de la literatura de consumo, con los romances de ciego y las "historias". El piscator setecentesco emplea todos los medios de alarde de inventiva para vender su producto y superar a los más famosos competidores. El éxito del nuevo género no pasó inadvertido y algunos escritores se aprovechan del título de pronóstico, y bautizan así sus escritos sólo por asegurar la venta. Como confiesa Pholt en 1735:

Valíme del título de pronóstico, porque veo que todo lo que lleva semejante frontispicio tiene pronto despacho.

En síntesis: el almanaque recoge un gran abanico de temas durante el siglo XVIII, entre los cuales figuran la muerte, la pobreza, la fantasía, la escatología, en textos que combinaban verso y prosa. El formato era siempre el mismo: los piscatores dividían su obra en juicio del año, pronóstico por estación, información mes por mes con signos del zodíaco, y un prólogo dirigido a un "amigo vulgo" que con suerte, a ristra de chistes, compraría sus papeles. El lector esperaba este orden predispuesto y luego la sorpresa que vendría con la innovación de la "historia" o cuento, con los personajes creados. La innovación vendría con la ficción (el cuento narrado), que se daría sobre este trasfondo de continuidad.

Comenzaré por identificar al lector concreto a través de un breve recorrido semántico y de estrategias textuales. El almanaque pertenece a la serie de géneros orales bajos - disparates, procacidades. Si adoptamos la propuesta de Bajtín sobre la risa carnavalesca ${ }^{10}$, pertenece tam-

${ }^{9}$ Ibid., pp. 193-195.

10 Mikhail Bakhtine, La poétique de Dostoievski, Seuil, Paris, 1970, p. 5. 
bién a la cultura de la risa, aún en sus formas de circulación y venta. Los piscatores incorporan varios niveles de lengua - la rústica aldeana, las prevaricaciones idiomáticas, etc. Su lenguaje paródico nos remite a la cultura de la risa, a la cultura carnavalesca, y a sus transgresiones éticas y morales. El mundo al revés, desacralizado, que exalta lo bajo corporal y sus placeres. En este entramado de apropiación e intercambio se produce y re-produce toda una nueva serie literaria - el piscator utópico, nuevo fautor de ilusiones, encantador que proyecta un mundo en el cual la nueva realidad se reconstituye por vías de la imaginación. Los códigos presentan un sistema semiológico muy completo: son mensajes codificados que el lector social concreto descodifica. Los prodigios que se cuentan dentro del código del carnaval y dentro de un calendario festivo - pues el almanaque se publica por Navidades, en el Nuevo Año- ejemplifican un mensaje destinado a revelar el futuro. De ahí que buena parte de los textos estén cubiertos de signos, que el receptor interpreta. Y si desde el siglo XVI la predicción y los vaticinios a menudo están relacionados con la represión social, dentro de los códigos de la cultura popular y carnavalesca, estos esquemas ideológicos se subvierten.

La fiebre de vaticinios aumentó a partir del resonado éxito de Diego de Torres Villarroel, que captó la amplitud y el potencial del género y los explotó como caja de resonancia para intercalar descripciones, monólogos y diálogos, dejando más espacio a la imaginación concretizadora del lector. Torres inicia una operación de alta acrobacia; su maestría consiste en incorporar el lenguaje popular coloquial en todo su realismo: la ficción le comunicaba al público una parcela de la realidad. Si bien comenzó a sueldo del Hospital de Pobres con el título de Sarrabal de Milán, pseudónimo de un astrólogo italiano famoso, pronto se emancipó y puso negocio propio, bautizándose con el nombre de Gran Piscator de Salamanca para componer sus propios pronósticos. Torres se vale de múltiples estrategias textuales gratas al paladar de su público determinado, acostumbrado a leer "papeles", "historias" fingidas, novedades y noticias sobre mundos exóticos y sorprendentes: monstruos, hazañas en países lejanos y desconocidos. No menos exótico o sorprendente era el mundo de la chismografía palaciega que animaba la imaginación de los lectores ofreciendo detalles escabrosos o chistosos sobre los grandes (especie de prensa amarilla). Los textos de Torres eran ricos en significados, e incorporaron temas al orden del día, en comunión de opiniones con el horizonte de expectativas de su público. El notorio oersonaje dio en el clavo y llegó a obtener fama y fortuna; no se trataba de enseñar -escribe en 1725 - sino de comer. Sus divertidos negocios estaban encaminados a aumentar la bolsa.

Su propia biografía, que comenzó a publicar por entregas en 1743, lo revela como personaje extravagante, con "algo de brujo", a quien le gustaba leer libros raros. Luego de obtener la cátedra de matemáticas en la Universidad de Salamanca, se convirtió en un escritor prolífi- 
co, que aprovechaba acertadamente los temas de moda, la magia, el chisme, lo sobrenatural. Torres registra además los nuevos estilos de vida, las variantes del habla. El placer de la fabulación, de contar mentiras, de narrar: deidades, nobles, plebeyos, personajes de voz y gesto se enredan y dialogan mientras se echan en cara el modo de cada cual para esquilmar a sus lectores. No obstante el deseo primordial de entretener, Torres - y otros piscatores- a menudo captaban las insatifacciones populares y presentaban tentativas de innovación política, envueltas en un cierto aire utópico. Sus fabulaciones satíricas ayudaron posiblemente a crear una actitud escéptica hacia lo extraordinario y sorprendente, con los briosos ataques a las supersticiones y a las falsas creencias del vulgo (que de todo se publicaba bajo el título de pronóstico). Torres y algunos de sus emuladores lucharon contra la ortodoxia rígida de las instituciones académicas, que se oponían a que la clase media, de status inferior pero más hábil y preparada, se integrase a la república de las letras.

Torres Villarroel añade mayor variedad de temas a las patrañas y mentiras características del género. Sus innovaciones son variadísimas y las implicaciones ideológicas claras: logró aplicar las matemáticas y la astronomía a las necesidades prácticas de sus lectores. Si el alquimista, como escribió el poeta metafísico John Donne, es aquel que saca a la luz y perfecciona el oro divino escondido en la burda realidad, Torres es el alquimista Midas burgués que transforma sus palabras en oro a través de la piedra filosofal del texto. Los lectores olvidaban así los rigores de la vida cotidiana. El salmantino y sus imitadores cobraron conciencia de que la felicidad y el bienestar eran el norte supremo de su público. Torres proyecta la imagen de una sociedad libre de los extremos de riqueza y pobreza, donde reina la hermandad. Su propósito es pragmático y utilitario. Así escribe en el "Prólogo general" a sus Obras completas ${ }^{11}$ :

Es la lección de muchos de ellos [almanaques] enseñanza, honra, y utilidad para la vida; la de algunos deleite, serenidad, y advertencia para el alma (OC, IX, 1739).

No hacen daño, y si fueron bien recibidos - aclara- se debe "a la miseria que había entonces de esta clase de estudio". La astrología es útil al estado; tiene valor didáctico, insiste. Precisa que él no escribe en jerga filosófica, ni física, porque escribe para el vulgo que desea informarse. Sus calendarios predican "con blandura, sin artificio" (OC, $\mathrm{X}, 1753$, p. 126). Aún más específica es su respuesta de 1726 a fray Martín Martínez, médico amigo de Feijoo, donde defiende la astrología como buena y cierta en lo natural, verdadera y segura en lo moral,

11 Extracto de los pronósticos del Gran Piscator, desde 1725 hasta 1753. Obras completas, Salamanca, 1752 , ts. IX y X. 
útil y provechosa en lo político $(O C, \mathrm{X}, \mathrm{pp} .136 s s)$. En definitiva, la astrología destierra "los errores", y en los pronósticos trabaja como filósofo, astrónomo, médico, matemático. Con cierta precisión, digna de tomarse en cuenta, distingue entre pronósticos y calendarios: los primeros se ocupan de eclipses, lunaciones, lluvias, truenos, cosechas, carestías, y los segundos son patrimonio de la Iglesia y deciden fiestas y vigilias. En otro momento señala que escribe "sin autoridad, citas, versos ni apoyos" (OC, IX , 1726), si bien esta juvenil socarronería se atempera con los años, y deja de ser "protomentecato y archi-salvaje".

En su Vida cuenta con humor que aprendió astrología en rancios y desconocidos libros que buscaba en las librerías más viejas. De las lecciones y tareas y las conversaciones con un clérigo salmantino docto, salió escribiendo pronósticos. Pero no todo es chiste, también importa la lección moralizadora, como vimos. Esta vertiente didáctica se afina con los años, y en el almanaque de 1753 descubre al público la seriedad de su empresa; después de treinta años de experiencia, mira retrospectivamente su profesión de astrólogo. Mis almanaques, dice,

están engendrados con la madurez, con la experiencia, y con la buena intención de corregir las acciones, y los pensamientos, para hacer feliz, sosegada y venturosa nuestra vida $(O C, \mathrm{X}, 1753, \mathrm{p} .123)$.

En definitiva, su éxito no tiene precedentes en el Antiguo Régimen y nadie alcanzó su fama. Razón no le falta al censor de un bachiller astrólogo al afirmar en 1747 que Torres es singular porque si bien son infinitos los piscatores, él es el único que disfraza la verdad con mentiras. En lo que llamaríamos hoy un excelente trozo de sociología literaria, el censor destaca que el éxito de Torres se debe a que supo alimentar el horizonte de expectativas de sus lectores:

el mundo vive tan enamorado de la mentira, que como la verdad para sus ojos es fea, en viéndola desnuda, huye ${ }^{12}$.

Mentira y verdad, riqueza y pobreza, muerte y vida, sueño y realidad son algunos ejemplos del tipo de oximoron violento en que se apoya el arte de Torres, contraste que Bajtín sugiere como categoría de la sátira menipea y de la tradición carnavalesca. Precisamente esos elementos son el sustrato de sus pronósticos, donde introduce además elementos de utopía social en forma de sueños, viajes. Otra característica que hay que tomar en cuenta es la mezcla de prosa y verso, los géneros intercalados que apoyan la preocupación por los problemas socio-políticos contemporáneos. En los polos de la violenta oposición, se subvierte y desmistifica la realidad: "tengo la manía de tomar al revés las cosas del 
mundo", escribe en 1744 (OC, IX, 1744, p. 121), y el mundo es "feria", "carnaval", "risa".

En cuanto creador de un nuevo género inserto en la tradición carnavalesca, Torres Villarroel y sus pares crearon una cosmología popular, atrayendo a sus lectores con el poder de la ciencia y prediciendo las maravillas de la naturaleza. Esta ciencia o cosmología popular era una especie de viaje fantástico que alimentaba el anhelo de progreso. El viaje fantástico no es ahora - como en sus otros escritos- a través de estamentos y estados, sino de regiones que presentaban tentativas de cambio. Si los almanaques se convirtieron en género de moda y alcanzaron difusión, se debe a que muchas de las fantasías narradas tocaban el centro mismo de los problemas cruciales de las masas populares: el anhelo de igualdad que podría finalmente armonizar las clases sociales del Antiguo Régimen. La situación comunicativa específica de este género - precio, lenguaje, temas, estilo- estaba determinada sociológicamente respecto a su público concreto, su público histórico determinado. Tentativas semejantes encontraremos en algunos de los ejemplos de género utópico que conocemos hoy: La Sinapia, y el Tratado sobre la monarquía columbina, anónimos de las postrimerías del setecientos ${ }^{13}$, con la diferencia de que este último es anti-ilustrado. Otras utopías son menos conocidas aún (si fuera posible): Aventuras de Juan Luis (1781) de Diego Ventura Rejón y Lucas, La eudamonopeia (1796), de Joaquín Traggia, aunque los viajes imaginarios abundan a finales del siglo. Pero muy otro es el cariz utópico de Torres Villarroel.

Los textos del salmantino presentan la igualdad o fraternidad utópica a través de parodias de un cierto tono democrático. Personajes de todas las clases sociales desfilan en los breves relatos en prosa, tan cercanos a la narrativa: pobres, gitanos, bachilleres, cortesanos, madamas, nobles. Esta mezcla de clases sociales se revela de manera paródica en el almanaque de 1730, donde Torres insiste en que el labrador, el duque y el noble tienen oportunidades semejantes para alcanzar la felicidad material en el mundo $(O C$, IX, 1730, p. 112). Su estrategia comunicativa del chiste y la ambigüedad es el sustrato del almanaque de 1749 , donde les redefine a sus lectores los personajes y títulos que emplea en los calendarios. Aclara que el rey del cual habla no es un soberano, sino el rey de espadas; los ministros no son aquellos que ostentan puestos importantes, sino la horda de sacristanes, acólitos, monaguillos y alguaciles; los poderosos no son los miembros de la alta nobleza, sino los escri-

13 Se viene estudiando más a estos autores. Además de F. López Estrada, op. cit., véanse los de F. LOPEZ, "Considérations sur La Sinapia", en La contestation de la societé dans la littérature espagnole du Siécle d'Or, Université de Toulouse-Le Mirail, Toulouse, 1981; S. Cro, "La utopía en España: Sinapia", CuLCH, 1980, núms. 2/3; Pedro Álvarez de Miranda (ed.), Tratado sobre la monarquía columbina. Una utopía antiilusirada del siglo xviii, El Archipiélago, Madrid, 1980 y "Sobre utopía y viajes imaginarios en el siglo XVIII español", Homenaje a Gonzalo Torrente Ballester, Salamanca, 351-382, si bien los textos se publicaron en la década de 1970 . 
bas; una dama no es una noble, sino una moza labradora de Galicia o Asturias; un señor no es de ningún modo un noble, sino un hidalguillo sin fortuna que es más alto que los demás (OC, X, 1749, pp. 59-62). Esta descripción paródica, rica en dobles sentidos, avivaba sin duda la pasión descifratoria de sus receptores. El productor y el receptor de la ficción conocían los registros connotativos de la comunicación. Este inciso paródico revela, además, la preocupación de Torres por el torbellino social. Funda su ficción sobre el horizonte de experiencias de sus receptores, que conocían en la realidad las ciudades hacinadas de pretendientes y pleiteantes, así como la desvergüenza y el desenfado de los hambrones.

El acierto mayor de las ficciones astrológicas de Torres Villarroel - justamente donde sus almanaques pisan el terreno de la utopía populares la forma en que pinta la vida y las ambiciones del estado llano. En contraste con el estilo de otros piscatores, no es la voz narrativa quien ofrece los vaticinios y perfila las críticas. Hablan sus personajes y éstos son, por lo común, representantes de las clases populares: soldados, labradores, artesanos. Cuando no los estereotipos literarios - viejas, brujas, pícaros, gitanos, locos. A través de los diálogos de sus personajes se ponen en tela de juicio las instituciones. El salmantino aprovecha el conocido tópico de que gitanos y locos mienten y que los soldados son fanfarrones y exagerados, para colar su crítica. El lector concreto podía subvertir el orden y leer el texto como una forma de crítica social, cercana a sus propios intereses, o bien tomarlo como juego y no prestarles mucha atención a las opiniones políticas implícitas o sugeridas en el texto. A Torres no se le escapa este tipo de lectura, pues subraya con frecuencia que las digresiones sobre cosas de gobierno eran metáforas y fantasías. Tocaba al lector hacer su propia interpretación, atrayéndolo así a una colaboración interpretativa-textual. En el piscator de 1732, Delirios astrológicos, advierte:

Siempre que escribo pronósticos, puedes creer que estoy delirando; pero el delirio de éste ha llevado mayor propiedad. Léelo, y no te descabeces en qué quieren decir los aforismos, pues te juro por mi vida que yo tampoco lo sé, y en ellos no encontrarás más sentido que el que tú les quieras dar (OC, IX, 1732, pp. 145-149).

En el de 1736, Los desahuciados del mundo y de la gloria, pide una colaboración más estrecha:

Aquí te queda mi argumento; prosigue la obra, o empieza de nuevo con su asunto; y si la mejoras, puedes decir que hallaste el medio de quedar tú glorioso, yo confundido, y el público aprovechado.

O risa o chiste, el vocabulario de Torres Villarroel repite con insistencia ciertos léxicos: embuste, trampantojo, desengaño, ociosidades (véanse 
los almanaques de 1743, 1744 y 1751). En algún momento escribe de manera muy directa que los abusos de los estamentos privilegiados han llevado a las clases pobres a robar y mentir $(O C, \mathrm{IX}, 1730$, p. 101), en consonancia con algunos de los juicios de La barca de Aqueronte (ca. 1731). De sus textos se desprende que la vida cotidiana podría mejorar si se aprende a hacer buen uso de las instituciones y leyes, y así los ciudadanos pueden llegar a ser útiles al estado. En definitiva, los textos de Torres mantienen las jerarquías sociales. Casi sin excepción sus fabulaciones tienen un final feliz, caro a sus lectores. Entonces el autor interviene directamente para insistir que los hombres pueden ser dichosos. (En este sentido, su utopia popular se asemeja a la utopía agraria formulada por Jovellanos ${ }^{14}$.)

El potencial de crítica velada de los piscatores no pasó desapercibido a la censura gubernativa; en 1766 Campomanes mandó a recoger el pronóstico de Bartolomé Ulloa y otro de Torres Villarroel, compuesto con su sobrino Isidro Ortiz Gallardo. "Estas obras - dice el oficioanuncian diferentes sucesos políticos, en forma de adivinanzas, que pueden traer siniestra interpretación; y su leyenda es perjudicial al público" "15. El oficio pone de relieve que el público de estos textos de ficción, al fundar su lectura sobre su propia experiencia, podría recibir un mensaje contrario a los intereses del estado. Censura semejante recibió Francisco de Valdemoros por su pronóstico de 1756, prohibido por sus desvergüenzas y su desenfado contra los ministros y el gobierno ${ }^{16}$. El "papel" provocó mayor severidad en las leyes de imprenta, hecho que resalta cómo el lector contemporáneo captaba todos los registros de la comunicación al reconstruir el texto y llenar los vacíos connotativos.

Las ficciones que Torres publica en sus almanaques son una especie de cuentos de hadas escritos por un adulto con el fin de entretener. Es probable que ni el autor ni los lectores creyeran a pie juntillas las patrañas, si bien ambos fundaban el acto comunicativo sobre su propia experiencia. Las fantasías que Torres elabora son semejantes a imágenes, iconos que animaban y avivaban la imaginación, ricas en significados e interpretaciones. Tomaba de la realidad elementos de ficción, al describir los mejores momentos, las horas de bienestar y felicidad: lo posible dentro de lo imposible $e^{17}$. En lugar de ser simplemente el anverso, la ficción le comunicaba algo sobre la realidad a sus lectores concretos (me apoyo en las sugerencias de Iser). Si reconstruimos el repertorio de significados del cual disponía el receptor contemporáneo de estos almanaques, se puede conjeturar que Torres proyecta el ideal de la ar-

14 Cf. Zavala, "Dreams of reality: enlightened hopes for an unattainable Spain", Studies in Eighteenth Century Culture, 6 (1976), 459-470.

15 Zavala, Clandestinidad..., pp. 207-208.

16 Ibid., pp. 337-340.

17 Tomo el término de P. Tillich, "Utopía and cultural renewal", en Utopias and utopian thought, ed. cit., pp. 296-309. 
monía de clases. De sus textos el lector concreto podía concluir que el triunfo y la fortuna estaban al alcance de cualquier hombre medio y de pocas letras. A éste le sería posible ascender socialmente si hacía buen uso de su ingenio y de su espíritu inventivo. En su mundo de ficción revelaba las características del self-made man que alcanzaba popularidad y éxito. El bienestar y la holgura son, en definitiva, los nortes de sus almanaques y el horizonte de expectativas de sus lectores.

Es preciso reconsiderar el papel del lector en este proceso comunicativo. En este recorrido de lectura, cabe la posibilidad que el destinatario contrastara algunos aspectos del texto con su propia experiencia vital y que la literatura sirviera de provocación para transformar la realidad. Es decir, que los textos de Torres ejercieran una función didáctica para romper con ciertas normas. La participación activa de sus lectores no sería simplemente la colaboración textual, sino adquirir conciencia de los mecanismos de la vida histórica. Cabe pensar que estos textos se leyeran a partir de una operación dialéctica entre autor y público; el autor suscitaba nuevos mundos posibles imaginarios, y los lectores reconstruían realidades posibles - realidades de la utopía- con los datos suministrados, y contrastaban su propia vida con las fabulaciones que el autor proponía. De ser así, el mundo de la ficción deja de ser un mundo contrario a la realidad, y es, en definitiva, un horizonte que revela el sentido del mundo a través de los ojos de otro ${ }^{18}$.

Los almanaques de Torres, como los de tantos otros piscatores que siguieron sus huellas, presentan un camino intermedio entre el sueño y la realidad. De su lectura histórica se desprende hoy que los hombres pueden ser felices y gozar de bienestar, que los soberanos y sus ministros son humanitarios y están empeñados en otorgar felicidad a sus súbditos. La utopía de Torres - y la del pronóstico del Antiguo Régimen-, presenta una sociedad donde las penurias desaparecen y el bienestar es ley de vida. Esta fortuna próspera puede ser el destino de cualquier burgués emprendedor, como el propio Torres, cuyos sólidos recursos económicos provenían de sus "papeles"; tengamos en cuenta que hacia 1753 ganó la importante suma de 4,400 reales ${ }^{19}$. Apeló a diversas razones ante su público; unas veces decía que era ajeno a ambiciones e intereses, o bien que escribía por necesidad para ayudar a sus padres, o que lo guiaba la intención de divertir. Al margen de verificar los motivos que confiesa, nuestro famoso Piscator de Salamanca supo convertir la literatura en bien de consumo, aprovechándose con fines puramente económicos. Cuanto desea - repite- es ganarse la vida, trabajar; aseveraciones así y otras del mismo aire revelan que el afán de lucro es fuerza motriz en su profesión de autor. No es el único rasgo que comparte con la mentalidad burguesa posterior; en otro momento escribe:

18 K. Stierle, “Réception et fiction”, Poétique, 39 (1979), 299-320.

19 M. y J.L. Peset ReIG, "Un buen negocio de Torres Villarroel", CuH, 93 (1973), 514-536. 
" ni a ti ni a otro tengo alquilada mi conciencia $[. .$.$] es mi conciencia$ casa muy propia, y me la quiero vivir'” (OC, IX, 1727, p. 51), acentuando su convicción en favor de la libertad personal, la libertad de expresión y la libertad de conciencia, valores todos defendidos posteriormente por la burguesía en marcha. En cuanto self-made man Torres intuye la importancia de estas libertades individuales, caballos de batalla del liberalismo decimonónico.

Los almanaques del siglo XviII, sobre todo los de Torres, defendían las virtudes sociales burguesas: honestidad, trabajo, frugalidad, corrección. Asimismo, abrieron camino a otras disyuntivas y preocupaciones posteriores, en particular los derechos naturales del hombre (bandera de lucha en el ocaso del setecientos), significativamente en cuanto se refiere al bienestar material, la libertad individual y el derecho a la propiedad privada. Los testimonios abundan; sirva de ejemplo el prólogo a su almanaque de 1725 donde, en diálogo polémico consigo mismo y con sus padres, reflexiona: estáte contento, porque si mientes una que otra vez, no le haces daño a nadie. En cambio, añade, las hordas de pretendientes destruyen con sus mentiras propiedad, honor y vidas $(O C$, IX, 1725, p. 5). Emisor y receptor son uno y el mismo; ninguno de los dos miente o engaña. Sin embargo, los pretendientes, los así llamados científicos, los médicos, los catedráticos se valen de la mentira y engañan. Este registro de profesiones, que hoy llamaríamos el establishment profesional e intelectual, explota la credulidad del vulgo; y en vena quevedesca, Torres arremete contra médicos y abogados, animado por el deseo de comunicarle un sentido de respeto propio a su público.

El salmantino descodificaba las leyes de la naturaleza (si bien de manera pseudocientífica) y comunicaba a sus lectores concretos un orden político ideal, donde las clases populares podrían enfrentarse a los profesionales y hombres de gobierno con un cierto sentido de dignidad y respeto propio. Sus pronósticos elogiaban muy especialmente a los labradores, depositarios de las virtudes morales y carentes de groseras ambiciones urbanas. La dicotomía campo/ciudad, frecuente en el género utópico, es también eje de su utopía popular. Como el costumbrismo posterior, Torres elogia al labrador, al campesino como depositario de la moral y la tradición; en contraste, en la urbe las clases se confunden, los pretendientes abundan y la moral es dudosa. La mentira y el engaño están geográficamente bien localizados.

Los astrólogos como Torres acentúan un Dios de los pobres que protege al pueblo de calamidades y que recompensa a aquellos honrados trabajadores dignos de su misericordia. Del pronóstico emerge un nuevo sentido ético, una higiene de vida fundada en la observación de la naturaleza, el respeto a la sabiduría popular y el conocimiento directo del mundo. Los piscatores recomiendan la virtud, la justicia y la caridad y son también, con frecuencia, portadores de un concepto secularizado del mundo. Glorifican, sobre todo, las virtudes cívicas fuera de los medios eclesiásticos y profesionales. 
Quedan otros elementos fundamentales en este vasto contexto de lo que he llamado utopía popular, que hemos de tomar en cuenta para reconstruir el repertorio del cual disponía el receptor original de la comunicación. Las tentativas de innovación social que comunicaban los textos de Torres distan mucho de ser una pintura cínica de la debilidad humana (frecuente en los autores de las minorías cultas del siglo XVII); más bien se pueden interpretar de forma práctica y optimista. Si algunas instituciones y medios profesionales eran ridículos, se debía a que coartaban el ascenso social a individuos de su propia clase. Torres invitaba a sus lectores a fundir la realidad con esa ambición que parecía ilusoria. Avivaba la imaginación de sus lectores abriendo la posibilidad de que éstos contrastaran aspectos de las narraciones con su propia experiencia, y percibieran como posible la aparente imposibilidad de ascender en el mundo profesional. Los textos de los piscatores a menudo refuerzan y transmiten la noción de que la producción literaria y el éxito profesional pueden ser camino de movilidad social. Para el escritor profesional ésta depende del público, del éxito popular, de las ventas y no de mecenas o de instituciones académicas.

Los pronósticos de Torres Villarroel nos permiten en la actualidad reconstruir, al mismo tiempo, el horizonte de esperanzas, temores y ambiciones de algunos sectores de los medios populares. Texto y lector dialogan y polemizan, y son pareja esencial en este proceso comunicativo, ya que Torres conoce a fondo su público. Se preocupó por saber lo que éste deseaba para esparcimiento y recreo o por afán de novedades, así como las verdades y sentencias que le gustaría ver trazadas. Avivaba la imaginación con narraciones sorprendentes, un lenguaje salpicado de chistes y sentencias, datos y conocimientos útiles, detalles socarrones, ambigüedades, chistes, juegos de palabras con doble sentido en textos ricos en significados. Detengámonos en algunos aspectos del lenguaje: abundan las referencias a lo bajo corpóreo - sudores, defecaciones, comilonas, embriaguez, golpes, enfermedades. Todo el mundo de la medicina se describe mediante referencias a tercianas, erisipelas, herpes, tabardillos, decúbito de estómago. El cuerpo se fragmenta, y la exageración, con propósito burlesco, tiende a concentrarse en ojos, nariz, boca, manos, piernas. Examinemos algunos casos donde se concentran ambos procedimientos carnavalescos. Un personaje entra

Hediendo a puto, apestando a juncia de nalgatorias, con sus regüeldos de vino, trastornado en la colambre de los vientres ( $O C, \mathrm{IX}, \mathrm{p} .103$ ).

En otro momento, un médico tiene "una cara más hedionda que el espíritu del hollín" ( $O C, \mathrm{IX}$, p. 117), o bien un personaje se quita las "lagañas del juicio", otro es "caga trincheras" - las referencias a la defecación sirven de punto de apoyo-, "cagada de lagarto", "cagada de gato negro". La nariz es con frecuencia "sabañón”, o bien la figura humana es "una tajada de melón", cuando no se recurre a nabos, ca- 
labazas, peras, por cierto, alusiones sexuales. Se ensaña con los prejuicios; así, un gallego es

ahíto de cuerpo, trompetero de mofletes, barrigón de ojos, barbado de aguijones [...] Era gordo de badajo, con un buen besugo por lengua, embotado de pronunciación, y un cencerro boyuno por boca (OC, IX, p. 219).

De igual manera ridiculiza y rebaja el arte de escribir: un texto es "un rebuzno", la astrología es un "estercolero". En este mundo al revés

Que los jueces, y las brujas todos chupamos, unos niños, otros cuartos $(\widetilde{O C}, \mathrm{IX}$, p. 120).

Por tanto "vivamos, pues, y bebamos".

Sus pronósticos se apoyan en la variada intertextualidad con los géneros orales bajos y la cultura de la risa. También en las parodias (o travestidos) de los géneros literarios cultos - Góngora, Quevedo, teatro lopesco, novela picaresca, Cervantes, textos filosóficos, médicos, matemáticos. Todo cabe si produce risa.

El autor mismo era una ficción hecha realidad; la ficción comunicaba algo sobre la realidad. Ésta es justamente la función y el efecto de sus textos; a través de los almanaques podemos hoy captar elementos del contexto social del Antiguo Régimen. El mundo de la ficción no se percibe como contrario a la realidad; sus imaginativas pero eficaces premisas utópicas motivaban a los aspirantes a escritor a aprovechar su ingenio para adquirir fama y fortuna. Los calendarios de Torres se caracterizan precisamente por esta innovación, pues motivaron a muchos aprendices de matemáticos o estudiantes desempleados a emanciparse de las instituciones tradicionales y unirse a la grey de iniciados y reinar en la república de las letras. Torres le volvió la espalda al público culto y al mundo de académicos y medios universitarios; sus interlocutores estaban bien localizados entre los que hoy llamaríamos baja y pequeña burguesía. Su innovación reside justamente en buscar otro público y romper con un sentido restringido de la comunicación literaria, ciencia indispensable en la literatura de consumo. Sus ficciones y su propia vida en cuanto "hombre de novela" comunicaban otras posibilidades de realidad al hombre medio. Este factor interpretativo - como vimos- no pasó desapercibido a la censura gubernativa que prohibía los textos no por lo que contenían, sino por la interpretación que les podrían dar los lectores. El estado percibe el potencial subversivo de estos textos aparentemente inofensivos.

En esta subversión de la realidad, el lector disponía de buen caudal de información y datos. Torres y sus imitadores lo mantenían al tanto de sus triunfos y de su fortuna. Su meteórica carrera, de la cual se jactaba, es particularmente importante para situar sus pronósticos dentro del terreno de la utopía popular. Los hechos son bien conocidos: hijo 
de un pequeño librero salmantino, escaló en breve tiempo las cumbres de la fama. Lejos de emplear el tradicional sistema de mecenazgo, medró entre nobles, escritores de prestigio, burgueses ricos y aprovechó ante todo al público en beneficio propio. Y la Vida no es el único documento; en su almanaque para 1734, Los sopones de Salamanca (impreso en 1733), se pinta con colores vivos. Padece infamia, miserias, tribulaciones desde 1732, en que Su Majestad lo arrojó de sus dominios; suplicó con un memorial (sin respuesta), y se defiende en público:

Yo fui en mi dichosa monarquía el escolar más famoso, más trabajador, más variamente eudito, y más pobre [...] Nunca solicité más premio, más satisfacción, ni más honores que trabajar...

Es "pobre, afrentado, estudioso, perseguido", si bien sus costumbres son las de un hombre que sólo tuvo inclinación a los libros, a los enfermos, al campo, al retiro, a la conferencia de sabios. Sólo los libreros e impresores - dice - se aprovechan. Pero lo que resalta es su fama, ya no por nobles parientes, sino por el trabajo y el estudio.

Es importante subrayar que los textos de Torres Villarroel no amenazaban el orden establecido, aunque se lanzara a satirizar profesiones y oficios. Torres acepta y defiende las jerarquías de la sociedad señorial y aspira a alcanzar la holgura y bienestar de los privilegios de clase. Algunos de sus lectores, atentos a su fama y fortuna, encontraban en él alimento para sus propios sueños y ambiciones materiales, cuando no consuelo para sus desventuras y fracasos. La vida de Torres es una utopía convertida en realidad; es, de hecho, una invitación a transformar la ficción en realidad.

En definitiva, Torres ofreció a su público la posibilidad de diálogo, y su discurso literario demuestra la estrecha comunicación entre autor y lector. Su objetivo era lograr una respuesta específica de parte de un receptor más o menos empírico: "amigo lector". Percibió la capacidad, aún no desarrollada, del público lector como sujeto activo en el proceso de producción literaria y en el consumo. En realidad, el consumo mismo fue el agente activo, corroborando así la reflexión de Marx en los Grundrisse: "La producción no sólo produce un objeto para el sujeto, sino un sujeto para el objeto".

El escritor salmantino manipula a su público. Sus almanaques estaban encaminados a avivar la imaginación y la pasión descifratoria de sus lectores. Sus estrategias comunicativas - que he resumido muy brevemente - no tenían como único objetivo entretener o adormecer la conciencia; más bien en cuanto utopía popular, subvertían el mundo de experiencias de sus lectores proyectando la ilusión óptica de la armonía de clases. El trabajo y el ingenio como sólidas fuentes de felicidad, bienestar y fortuna. Al correr del tiempo, el género creado por Torres languidece; el público lector parece descubrir una función comunicativa semejante en los periódicos, los cuadros de costumbre y la novela bur- 
guesa. Pero esta variación de sentido y de gusto, de cambios o adaptaciones posteriores, podría tal vez explicarse si tomamos en cuenta que el nuevo lector concreto busca en otros textos el contraste con su propia experiencia vital distinta en elementos contextuales.

Los calendarios a los que me he referido carecen de un sentido filosófico-político coherente, así como de las sutiles y complejas teorías que sustentan los tratados utópicos cultos. No obstante, los elementos que he destacado - sociales e intelectuales, reales y emocionales- permiten reconstruir algunos aspectos de una coyuntura histórica específica, en que el bienestar económico del orden burgués se perfila como agente transformador de la historia. En sus almanaques Torres transformaba el horizonte de experiencias de sus lectores resolviendo diferencias de fortuna y alimentando fantasías sociales, y lo mismo hacían sus imitadores. Su lector podía inferir que el hombre medio podía alcanzar seguridad, bienestar económico y propiedad. La utopía textual se convierte en realidad; la ficción comunica que es posible un orden nuevo y una sociedad distinta ${ }^{20}$. El texto literario es así "una de las formas de la lucha de la humanidad por una verdad que le resulta necesaria', función que precisa de manera rotunda Yuri Lotman.

IrIS M. ZaVALA

Rijksuniversiteit Utrecht.

20 En otra palabras, como precisa ISER: "en lugar de ser simplemente su contrario, la ficción nos comunica algo sobre la realidad” (op. cit.). O, según K. STIERLE, art. cit., un horizonte que nos revela el mundo a través de los ojos de otro. 